https://doi.org/10.17048/AM.2020.321

\title{
Rajna Franciska
}

Eszterházy Károly Egyetem, Informatikai Kar

rajnafranciska45@gmail.com

\section{A kommunikációs gráfok és a fekete-fehér SAT probléma közti össze- függések vizsgálata}

\section{Absztrakt}

Ebben a cikkben a kommunikációs gráfok és a fekete-fehér SAT probléma közötti összefüggéseket vizsgálom. A kommunikációs gráfok olyan speciális hurokélmentes irányított gráfok, amelyeknek csúcsai logikai változók, az élei pedig a kommunikációt reprezentálják. Ilyen típusú gráfokkal lehet többek között vezeték nélküli szenzorhálózatokat is modellezni.

A cikkben bemutatom a fekete-fehér SAT problémát. A fekete-fehér SAT problémák olyan logikai formulák, amelyek majdnem kielégíthetetlenek, csak két megoldásuk van, az úgynevezett fehér hozzárendelés, ahol minden változó igaz, és a fekete hozzárendelés, amelyben minden változó hamis. A fekete-fehér SAT problémák ekvivalensek az olyan konjunktív normálformában lévő logikai formulákkal, amelyekben minden klózban pozitív és negatív literálok vegyesen szerepelnek (például ilyen 3SAT klózok a -++, --+), de sem a fehér klóz, amelyben minden literál pozitív, sem a fekete klóz, amelyben minden literál negatív, nem vezethető le. Továbbá ismertetem, és hatékonyság szempontjából elemzem a kommunikációs gráfok különböző logikai modelljeit (Erős modell, Balatonboglár modell, Egyszerűsített BB modell, Gyenge modell).

Kulcsszavak: fekete-fehér SAT probléma, kommunikációs gráf, Erős modell, Gyenge modell, Balatonboglár modell, Egyszerüsített Balatonboglár modell

\section{Investigation of the relationship between communication graphs and the black and white sat}

In this article, I examine the relationships between communication graphs and the black-andwhite SAT problem. Communication graphs are special loop-free directed graphs whose vertices are logical variables and whose edges represent communication. These types of graphs can be used to model wireless sensor networks (WSNs), among other things. 
I present the black-and-white SAT problem. Black-and-white SAT problems are logical formulas that are almost unsatisfiable, they have only two solutions, the so-called white assignment, where all variables are true, and the black assignment, in which all variables are false. Black-and-white SAT problems are equivalent to logical formulas in a conjunctive normal form in which positive and negative literals are mixed in each clause (e.g., such 3-SAT clauses are,-++-+ ), but not the white clause in which all literals are positive, nor the black clause in which all literals are negative cannot be deduced. I also describe and analyze the different logical models of communication graphs (Strong model, Balatonboglár model, Simplified BB model, Weak model) in terms of efficiency.

Keywords: black-and-white SAT problem, communication graph, Strong model, Weak model, Balatonboglár model, Simplified Balatonboglár model

\section{Bevezetés}

A napjainkban népszerű loT (Internet of Things) szorosan kapcsolódik a vezeték nélküli szenzorhálózatokhoz, hiszen hálózatba kötött „,intelligens” eszközöket használ, amelyekben beépített érzékelők és szenzorok képesek adatokat gyűjteni.

A vezeték nélküli szenzorhálózatok (Wireless Sensor Networks - WSNs) új alkalmazásokat tesznek lehetővé, továbbá az alacsony készülék-bonyolultság és az alacsony energiafogyasztás (azaz a hosszú hálózati élettartam) követelménye miatt meg kell találni a megfelelő egyensúlyt a kommunikáció és a jel/adatfeldolgozás képességei között. Ezen hálózatokat számos területen lehet alkalmazni, ilyen például a szeizmikus tevékenységek, az akusztikus és radarjelek monitorozása.

A szenzorok a hálózat csomópontjainak tekinthetők. A szenzorok képesek információfeldolgozásra, valamint vezeték nélküli kommunikációra. (Akyildiz és Su, 2002; Bharathidasan és Ponduru; Biró és Kusper, 2014; Bolic et al., 2018)

13. ábra Szenzorok elhelyezkedése

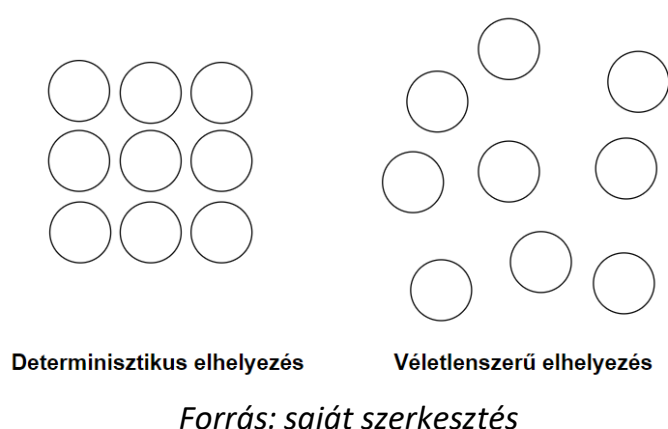

Forrás: saját szerkesztés 
Ahogy az 1. ábrán is látható a szenzorok elhelyezése történhet determinisztikusan vagy véletlenszerűen. A szenzor elhelyezkedését nagymértékben befolyásolják az adott terület vagy épület tulajdonságai. További fontos jellemzőjük ezen hálózatoknak a csomópontok típusai.

Megkülönböztetünk heterogén és homogén szenzorokból álló hálózatokat (2. és 3. ábra). Az olyan előnyök mellett, mint az alacsony energiafelhasználás vagy a könnyű és olcsó telepíthetőség mellett számos hátránya is van. Előfordulhatnak energiaellátási problémák, kommunikációs zavarok, hardware-es hibák, de esetleges rosszindulatú támadások is. Ezek nagyban befolyásolják a hálózat hibatűrő képességét. (Akyildiz és Su, 2002; Bharathidasan és Ponduru, 2002; Biró és Kusper, 2014; Bolic et al., 2018)

\section{2. ábra Heterogén szenzorokból álló hálózat}

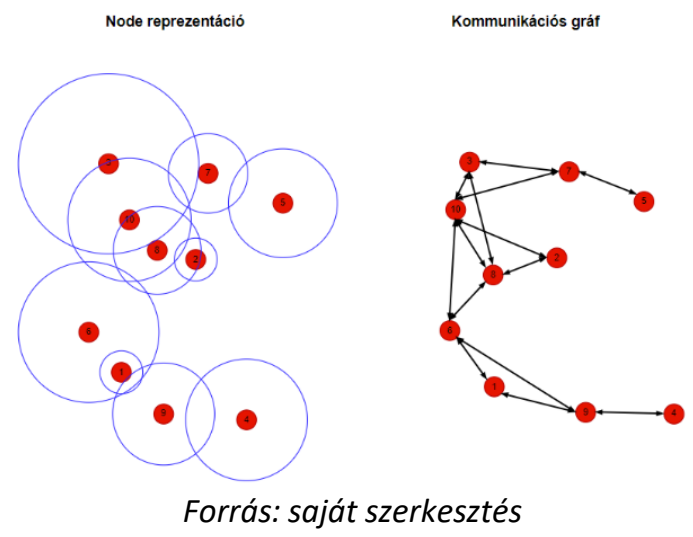

\section{3. ábra Homogén szenzorokból álló hálózat}
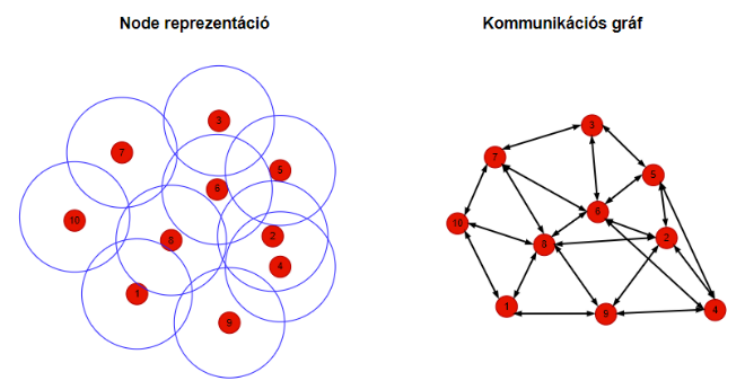

Forrás: saját szerkesztés

Napjainkban a legintenzívebben kutatott terület a szenzorok elhelyezésének optimalizálása, a hatékonyabb energiafelhasználás, kommunikáció és a megfelelő szintű hibatűrő képesség biztosításának érdekében.

A következőkben röviden bemutatásra kerülnek olyan információk, amik később nélkülözhetetlenek lesznek a modellek megértéséhez. 


\subsection{SAT probléma}

SAT probléma alatt a konjunktív normálformában (CNF) szereplő formulák logikai kielégíthetőségét (Satisfiability) értjük. A SAT az egyik legtöbbet kutatott NP-teljes probléma (KUsper et al., 2020b) a számítástechnika számos területén. Valamely 0-rendű logikai formula változóihoz olyan hozzárendelést keresünk, amely mellett a formula igaz.

A SAT formulákat DIMACS CNF fájlformátumban szokás az algoritmusok bemeneteként megadni. Ezek azért hasznosak, mert különböző SAT solverek-ek futási idejét tudjuk tesztelni velük. Ebben az esetben a literálok pozitív vagy negatív egész számként vannak jelölve. A bemenet minden egyes sora egy klóznak felel meg, amely sor végére nulla kerül.

Ha SAT problémáról beszélünk, akkor a formula speciálisan konjunktív normál formában van.

\section{1. egyenlet Konjunktív normálforma}

$$
\left(\neg x_{1} \vee x_{2} \vee x_{3}\right) \wedge\left(\neg x_{2} \vee x_{3} \vee x_{4}\right) \wedge\left(\neg x_{3} \vee x_{1} \vee x_{4}\right)
$$

Ilyenkor a formulánk csak az $\Lambda, \vee$ és $\neg$ operátorokat tartalmazza (1.egyenlet). Mint említettem a SAT probléma NP-teljes probléma, azaz minden NP-nehéz probléma visszavezethető effektíven SAT problémára.

A 1. egyenletben látható példára visszatérve, a konjunktív normál formában lévő kifejezés estén a DIMACS CNF a következő:

$F=\left(\neg x_{1} \vee x_{2} \vee x_{3}\right) \wedge\left(\neg x_{2} \vee x_{3} \vee x_{4}\right) \wedge\left(\neg x_{3} \vee x_{1} \vee x_{4}\right)$

\section{DIMACS CNF:}

c komment

$p \operatorname{cnf} 43$

$-1230$

$-2340$

$1-340$

A SAT problémának különböző típusai vannak. A 2-SAT (2-kielégíthetőség) a SAT probléma egy korlátozása, ekkor minden tag pontosan két literált tartalmaz. A SAT NP-teljes probléma mivel nincs ismert, hatékony megoldás rá. Viszont NP teljes problémáról csak $k \geq 3$ esetben beszélünk. A 2-SAT azonban hatékonyan megoldható az $O(n+m)$, ahol $n$ a változók száma és $m$ a klózok száma. A 3-SAT szintén a SAT egy korlátozása, ahol minden tag pontosan 3 literált tartalmaz. (Cook, 1971, Davis et al., 1962; Biere et al., 2009) 


\subsection{Hálózat kommunikációs gráfja}

Kommunikációs gráf alatt egy irányított gráfot értünk. $D_{S}=\left(S ; E_{C}\right)$, ahol $E_{C} \subseteq S \times S$. Egy $\left(\mathrm{x}_{\mathrm{i}}, \mathrm{x}_{\mathrm{j}}\right) \in E_{C}$ él azt jelenti, hogy $D_{s}$-ben az $\mathrm{x}_{\mathrm{i}}$ csomópontból az $\mathrm{x}_{\mathrm{j}}$-be üzenetet lehet küldeni. Azaz $\mathrm{x}_{\mathrm{i}}$ üzenetet küldhet $\mathrm{x}_{\mathrm{j}}$-nek, ha $\mathrm{x}_{\mathrm{j}}$-nek $\mathrm{x}_{\mathrm{i}}$ az átviteli tartományában van. Homogén szenzorok esetén a $D_{s}$ gráf szimmetrikus, ennek megfelelően a $D_{S}=\left(S ; E_{C}\right)$ egyenértékű egy egyszerű irányítatlan $G_{S}=\left(S ; E_{C}\right)$ gráffal.

Ebben a modellben a kommunikációt logikai implikációval definiáljuk. Ha az $x_{1}$ érzékelő képes üzenetet küldeni az $x_{2}$ és az $x_{3}$ érzékelőknek egyaránt, akkor a modell:

$\left(x_{1} \supset x_{2}\right) \wedge\left(x_{1} \supset x_{3}\right)$.

Felhasználva az előzőleg bemutatottakat, ennek a modellnek a konjunktív normál formája:

$\left(\neg x_{1} \vee x_{2}\right) \wedge\left(\neg x_{1} \vee x_{3}\right)$

\subsection{Fekete-Fehér SAT probléma}

A Fekete-fehér SAT probléma, annyiban különbözik a SAT problémától, hogy ez a logikai formula majdnem kielégíthetetlen. A SAT-probléma akkor és csak akkor fekete-fehér SAT-probléma, ha csak két megoldása van: a fekete hozzárendelés, ahol minden változó hamis, és a fehér hozzárendelés, ahol minden változó igaz. Ekkor a fehér hozzárendelésnél minden változó igaz, míg a másik esetben minden változó hamis. Ezek a SAT problémák ekvivalensek az olyan logikai KNF formulákkal, ahol minden klózban pontosan egy pozitív és egy negatív literál van. Azaz minden klóz bináris, de sem a fehér, sem a fekete klóz nem vezethető le belőle. (Biró és Kusper, 2018)

\section{4 Általános reprezentáció}

A 2.egyenletben látható az általános formula, ami egy modellből (M) és a megszorítás negáltjából áll $(\neg C)$.

\section{2. egyenlet Általános formula}

$\mathrm{M} \wedge \neg \mathrm{C}$

Egy irányítatlan gráfot át tudunk fordítani SAT problémává. Ekkor a modell minden esetben változik, de a megszorítás ugyanaz marad. Esetünkben a megszorítás egy kérdésnek fog megfelelni: ez pedig az, hogy „Minden csomópont tud a másikkal kommunikálni?”. (Biró és Kusper, 2018)

A következő példában arra a kérdésre adunk választ, hogy az alábbi ábrán látható $a, b, c$ csúcsok tudnak-e egymással kommunikálni. Ekkor a megszorítás (C) a 3. egyenletben látható.

\section{3. egyenlet A KNF-re hozott alak}

$(\neg a \vee b) \wedge(\neg b \vee a) \wedge(\neg a \vee c) \wedge(\neg c \vee a) \wedge(\neg b \vee c) \wedge(\neg c \vee b)$ 
A megszorítás negáltja $(\neg C)$ egyszerúsítések után a következő: $(\neg a \vee \neg b \vee \neg c) \wedge(a \vee b \vee c)$. Itt az első klóz a fekete hozzárendelés, míg a második a fehér hozzárendelés.

A modellek és a megszorítás negáltjának konjunkciójának lehetséges kimenetei:

a. Az eredmény UNSAT, vagyis kielégíthetetlen. Ekkor az eredeti kérdésünkre a válasz igen lesz, ami azt jelenti, hogy a modell megfelel a követelményeknek. A kommunikációs gráf erősen összefüggő.

b. Ha pedig SAT, vagyis kielégíthető, akkor nem lesz a válasz a kérdésre, tehát a modell nem felel meg a követelményeknek. A kommunikációs gráf nem összefüggő.

\section{Modellek}

Kutatásom során 4 modell vizsgálatában vettem részt, amiket hatékonyságuk alapján vizsgáltam, és hasonlítottam össze.

\subsection{Erős modell}

Az első ilyen az erős modell volt. A logikában egy irányított gráf élét a következőképpen ábrázolhatjuk $\mathrm{a} \rightarrow \mathrm{b}$. Tehát implikációt kell használni, vagyis $(\mathrm{a} \Rightarrow \mathrm{b})$, tehát $\mathrm{az} \mathrm{a} \rightarrow \mathrm{b}$ él ábrázolható bináris klózzal: $(a \Rightarrow b) \wedge(a \Rightarrow c)$, amely ekvivalens kettő 2-klózzal $(\neg a \vee b) \wedge(\neg a \vee c)$.

Ezt hívjuk irányított gráfok erős modelljének (Strong Model - SM). Legyen $D=(V, E)$ egy kommunikációs gráf, ahol $V$ a $D$ csúcsainak halmaza, $E$ pedig $D$ éleinek halmaza. Ekkor $D$ erős modelljét $S M$-el jelöljük, és a következőképpen definiáljuk: $S M:=\{\{-a, b\} \mid(a, b) \in E\}$. (Kusper et al., 2020a)

\subsection{Balatonboglár (BB) modell}

Második modellünk, a Balatonboglár modell azt a trükköt használja, hogy az egyes ciklusok detektálása helyett minden útból generál egy $a \rightarrow b \rightarrow c$ következő 3-klóz: ( $a \vee \neg b \vee c)$ ), amely negatívnegatív-pozitív (NNP) alakú klóz, még akkor is, ha nincs olyan ciklus, amely tartalmazza az $a$ és $b$ csúcsokat. Ez az egyszerúsítés lehetővé teszi a 3-SAT probléma gyors generálását irányított gráfból, és a SAT példány fekete-fehér 3-SAT lesz, ha a bemenetre az irányított gráf erősen összefüggő. Másrészt ez sok felesleges klózt generál, a klózok 99,99\% felesleges. (Kusper et al., 2020a, 2020b)

\subsection{Egyszerüsített Balatonboglár modell}

A fent említett probléma leküzdése érdekében mutatom be az Egyszerúsített Balatonboglár modellt (Simplified Balatonboglár model -SBB). Ebben a modellben létrehozzuk a gráf erősen összefüggő összetevőit. Minden komponenshez létrehozunk egy ciklust, amely tartalmazza az összetevő ös-- 
szes csomópontját. Ezután minden ilyen ciklushoz NNP klózt generálunk. Például az $\left(\mathrm{n}_{1}, \mathrm{n}_{2}, \ldots, \mathrm{n}_{\mathrm{k}}\right)$ ciklushoz elóállítjuk az $\left\{\left\{\neg n_{1}, \neg n_{2}, n_{3}\right\}, \ldots,\left\{\neg n_{k}, \neg n_{1}, n_{2}\right\}\right\}$.

Miután bemutattuk a nagy ciklusokat és a közöttük lévő kapcsolatokat, törölhetjük azokat az éleket, amelyek felépítik őket, és az ellenkezőket is. Az élek többi része „belső él”, amelyek ciklusokat alkothatnak, úgynevezett „belső ciklusokat”. Egyenként egy NNP klózzal képviseljük őket, így a pozitív literálnak szomszédos csomópontnak kell lennie az egyik negatív nagy ciklusán. Ezután töröljük azt az élt, amelyet negatív literálok képviselnek, és annak ellentétét. Addig tesszük ezt, amíg nem marad belső ciklusunk. (Kusper et al., 2020a, 2020b)

\subsection{Gyenge modell}

Az utolsó modellünk a Gyenge modell (Weak modell - WM). Az ötlet a következő: Ha egy gráf két élt tartalmaz: $a \rightarrow b$, és $a \rightarrow c$, akkor ezeket a következő képlettel ábrázolhatjuk: $(a \Rightarrow b) \vee(a \Rightarrow c)$, amely egyenértékű egy 3-klózzal ( $\neg$ a b $\vee c$ ). Továbbá a gráf ciklusait is képviselnünk kell. Ha $\mathrm{a}_{1}$ $\rightarrow a_{2} \rightarrow \cdots \rightarrow a_{n} \rightarrow a_{1}$ egy ciklus $b_{1}, b_{2}, \ldots, b_{m}$, kilépési pontokkal, akkor ezt a ciklust a következő klózzal lehet ábrázolni: $\left(\neg a_{1} \vee \neg a_{2} \vee \cdots \vee \neg a_{n} \vee b_{1} \vee b_{2} \vee \cdots \vee b_{m}\right)$. (Kusper et al., 2020a, 2020b)

\subsection{Különböző modellek összehasonlítása}

Az különböző modellek összehasonlítását a következő példán keresztül szeretném szemléltetni.

\section{4. ábra Egy erősen összefüggő gráf 4 csúccsal és 6 körrel}

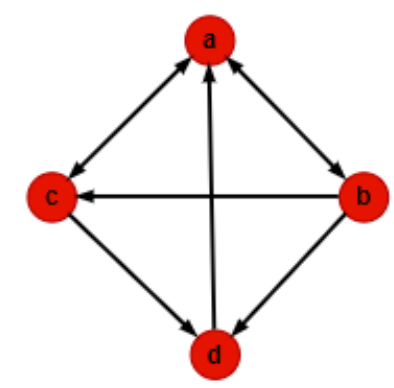

Legyen adott a 4. ábrán látható erősen összefüggő gráf, amely négy csúcsból és nyolc élből ál. Mivel a gráf 8 élt tartalmaz így az erős modell 8 darab 2 hosszúságú klózból fog felépülni.

$$
S M=\{\{\neg a, b\},\{\neg a, c\},\{-b, a\},\{\neg b, c\},\{-b, d\},\{\neg c, a\},\{-c, d\},\{\neg d, a\}\}
$$

A gyenge modellnél az első 4 klóz a csúcsok reprezentációja, a többi 5 klóz pedig a köröket reprezentálja. A körök reprezentálásánál negatív literálokkal jelöljük a körön belüli csúcsokat, és pozitívokkal a lehetséges kilépési pontokat. 
$W M=\{\{\neg a, b, \quad c\}, \quad\{\neg b, \quad a, \quad c, d\}, \quad\{\neg c, a, \quad d\}, \quad\{\neg d, \quad a\}$, $\{\neg a, \neg b, c, d\},\{\neg a, \neg b, \neg c, d\},\{\neg a, \neg c, b, d\}$,

$\{\neg a,-b, \neg d, c\},\{\neg a, \neg c, \neg d, b\}\}$

Nézzünk meg egy-egy klózt részletesebben. Az első legyen a b csúcshoz tartozó reprezentáció:

$\{-b, a, c, d\}$.

A ᄀb mutatja, hogy melyik csúcsról van szó, az $a, c, d$ pedig azt, hogy a $b$ csúcsból ebbe a három csúcsba vezet kimenő él.

Most pedig nézzünk meg egy kört reprezentáló klózt, például a következőt:

$\{\neg a,-b, \neg d, c\}$.

A negatív literálok reprezentálják az adott kört: $\neg a, \neg b, \neg d$, a pozitívak pedig, esetünkben csak a $c$, azokat a csúcsokat, amelyekbe az adott körből el lehet jutni.

Mint a gyenge modellnél, a Balatonboglár modellben is az első 4 klóz a csúcsok reprezentációja, annyi különbséggel, hogy itt maximum két csúcsot vehetünk figyelembe. Ha van egy olyan csúcs, amelynek 10 kimenő éle van (10 közvetlen szomszédja), akkor ezek közül tetszőlegesen válaszhatunk kettőt, a többit nem tároljuk. A Balatonboglár modell 3-SAT probléma, tehát csak kettő és három hosszúságú klózokból állhat.

$$
\begin{aligned}
& B B=\{\{\neg a, b, c\},\{\neg b, c, d\},\{\neg c, a, d\},\{\neg d, a\}, \\
& \{\neg a, \neg b, c\},\{\neg a, \neg b, d\},\{\neg a, \neg c, b\},\{\neg a, \neg c, d\}, \\
& \{\neg b, \neg c, a\},\{\neg b, \neg c, d\},\{\neg b, \neg d, a\},\{\neg c, \neg d, a\}, \\
& \{\neg d, \neg a, b\},\{\neg d, \neg a, c\}\}
\end{aligned}
$$

Az Egyszerűsített Balatonboglár modellnél a csúcsok reprezentációja ugyanaz lesz, mint a Balatonboglár modellnél, de a körök reprezentálásánál a klózok fele kiesik, csak egy kilépési pontot veszünk már figyelembe.

$$
\begin{aligned}
& S B B=\{\{\neg a, b, c\},\{\neg b, c, d\},\{\neg c, a, d\},\{\neg d, a\}, \\
& \{\neg a, \neg b, c\},\{\neg b, \neg c, d\},\{\neg c, \neg d, a\}, \\
& \{\neg d, \neg a, b\},\{\neg a, \neg c, d\}\}
\end{aligned}
$$




\section{3. Összefoglalás}

Ebben a cikkben ismertettem és elemeztem a kommunikációs gráfok és a fekete-fehér SAT problémák közötti összefüggéseket. Célom ezzel az volt, hogy rávilágítsak az egyes modellek közötti különbségekre, illetve, hogy a modellek segítségével mennyire hatékonyan reprezentálhatók ezen problémák.

Az elemzések során kiderült, hogy az erős és a gyenge modellek között lévő Balatonboglár és az Egyszerűsített Balatonboglár modell közül a Balatonboglár modell redundánsabban írja le a problémát, mint az Egyszerűsített Balatonboglár modell, ezért a többi modellhez képest hatékonysága elhanyagolható. Továbbá rávilágítottam arra, modelleknek van egy közös tulajdonsága, mégpedig az, hogy egy erősen összefüggő irányított gráf modellje fekete-fehér SAT probléma.

A továbbiakban célom a bemutatott 4 modell közül a gyenge modell további tulajdonságainak vizsgálata, többek között a minimális UNSAT magjának meghatározása.

\section{Irodalomjegyzék}

I.F. Akyildiz, W. Su*, Y. Sankarasubramaniam, E. Cayirci Wireless sensor networks: a survey Computer Networks 38 (2002) 393-422

\section{https://doi.org/10.1016/S1389-1286(01)00302-4}

A. Bharathidasan, V. A. S. Ponduru, Sensor Networks: An Overview, 2002.

A. Biere, M. Heule, H. van Maaren, T. Walsh, Handbook of Satisfiability. IOS Press, Amsterdam, 2009.

Biró Csaba, Kusper Gábor, SAT reprezentációk vezeték nélküli szenzorhálózatokhoz, Networkshop 2014. http://nws.niif.hu/ncd2014/docs/ehu/109.pdf

Biró, Csaba, and Kusper, Gábor. "Equivalence of strongly connected graphs and black-and-white 2SAT problems." Miskolc Mathematical Notes 19.2 (2018): 755-768.

https://doi.org/10.18514/MMN.2018.2140

Bolic, Miodrag, Simplot-Ryl, David Stojmenovic, Ivan (eds.) RFID Systems - Research Trends and Challenges 2010. 576 Pages, ISBN 978-0-470-74602-8 - John Wiley \& Sons

https://doi.org/10.1002/9780470665251

S. A. Cook., The Complexity of Theorem-Proving Procedures. Proc. of STOC'71, pp. 151-158, 1971. https://doi.org/10.1145/800157.805047

M. Davis, G. Logemann, D. Loveland., A Machine Program for Theorem Proving. Commun. ACM, vol. 5, no. 7, pp. 394-397, 1962.

\section{https://doi.org/10.1145/368273.368557}


Kusper, Gábor; Biró, Csaba; Balla, Tamás. Representing Directed Graphs as 3-SAT Problems using the Simplified Balatonboglár Model. In: The 11th International Conference on Applied Informatics to be held in Eger. 2020.

Kusper, Gábor, Csaba Biró, and Tamás Balla. "Investigation of the Efficiency of Conversion of Directed Graphs to 3-SAT Problems." 2020 IEEE 14th

https://doi.org/10.1109/SACl49304.2020.9118786

International Symposium on Applied Computational Intelligence and Informatics (SACl). IEEE, 2020.

S. A. COOK, The Complexity of Theorem-Proving Procedures, Proc. of STOC'71, pp. 151-158, 1971 https://doi.org/10.1145/800157.805047 